\title{
Ekonomik Büyüme İle Üretim Faktörleri Arasında Ekonometrik Bir Analiz: Türkiye Örneği (1980-2016)
}

\author{
Jiyan KILIÇ ${ }^{l}$ \& Illkay DILBER ${ }^{2}$
}

\section{Özet}

Ekonomik büyümenin temel yapı taşlarını sermayenin, emeğin ve teknolojik gelişmelerin oluşturduğu birçok iktisatçı tarafindan kabul görülmektedir. Bu temel bileşenlerin ekonomik büyüme ile kısa veya uzun dönemli ilişkinin varlığı ve kuvveti çalışmanın araştırma konusunu oluşturmaktadır. Bu çalışmada, Türkiye için 1980-2016 dönem aralığını kapsayan yıllık zaman serileri kullanılarak ekonomik büyüme ve üretim faktörleri arasındaki ilişki incelenmiştir. Oluşturulan modelin bağımlı değişkeni Gayri Safi Yurtiçi Hasıla (Y) iken bağımsız değiş̧kenlerini sermaye miktarı (K), emek miktarı (L) ve teknolojik gelişmeyi ifade eden toplam faktör verimliliği (A) olușturmaktadır. Değișkenler arasındaki ilișki ADF ve PP birim kök testleri, Johansen Eşbütünleşme Testi ve Vektör Hata Düzeltme Modeli (VECM) ile test edilmiştir. Elde edilen bulgular doğrultusunda; değişkenler arasında uzun dönemli nedensellik ilişkisi olduğu sonucuna ulaşılmıştır. Ayrıca, sermaye ve emek miktarından ekonomik büyümeye doğru kısa dönemli nedensellik ilişkisi tespit edilirken, toplam faktör verimliliğinden ekonomik büyümeye doğru kısa dönemli nedensellik ilişkisi bulunamamıştır.

Anahtar Kelimeler: Ekonomik Büyüme, Üretim Faktörleri, Johansen Eşbütünleşme Testi

\section{Econometic Analysis Between Economic Growth And Production Factors: The Case Of Turkey (1980-2016)}

\begin{abstract}
The basic building blocks of economic growth are accepted by many economists of capital, labor and technological developments. The existence and strength of short-term and long-term relationships with economic growth of these basic components constitute the research topic of the study. In this study, the relationship between economic growth and the factors of production using annual time series covering the period 1980-2016 range for Turkey were examined. While the dependent variable of the model created is the Gross Domestic Product (Y), the independent variables are the amount of capital $(\mathrm{K})$, the amount of labor $(\mathrm{L})$ and the total factor productivity (A) which is representing technological development. The relationship between variables was tested with ADF and PP unit root tests, Johansen Cointegration Test and Vector Error Correction Model (VECM). According to the findings; it was concluded that there is a long-term causality relationship between variables. In addition, while short-term causality was determined from the amount of capital and labor to economic growth, there was no short-term causality relationship from total factor productivity to economic growth.
\end{abstract}

Key Words: Economic Growth, Production Factors, Johansen Cointegration Test

${ }^{1}$ Doktora Öğrencisi, İzmir Demokrasi Üniversitesi, Sosyal Bilimler Enstitüsü, İktisat Bölümü, jikilic@gmail.com

${ }^{2}$ Doç. Dr., Manisa Celal Bayar Üniversitesi, İktisadi ve İdari Bilimler Fakültesi, İktisat Bölümü, ilkay.dilber@cbu.edu.tr 


\section{Giriş}

Bir ekonomide, üretimin gerçekleşebilmesi için fiziksel sermaye stoğu önemli bir yere sahiptir. Fiziksel sermaye stoğu, mikro açıdan üretim sürecinde uzun yıllar kullanılabilen makine, teçhizat, bina iken makro düzeyde karayolu, havayolu, demiryoluna yapılan yatırımlar, barajlar gibi altyapı yatıımlarıdır (Songur 2017: 202). Hem mikro hem de makro açıdan ele alınan fiziksel sermaye stoğu, üretim sürecine girerken emek faktörünün verimliliğini arttırmaktadır.

İktisat literatüründe ekonomik büyümenin temel belirleyicileri sermaye, emek ve teknolojik gelişme olarak birçok iktisatçı tarafından kabul edilmektedir. Fakat, Neo-klasik büyüme modeli temel varsayımlarını dikkate alarak ve sermaye faktöründe azalan verimler yasasının geçerli olmasından dolayı uzun dönemde, Solow'un (1956) kurduğu modele göre ekonomik büyümeyi belirleyen temel faktörün teknolojik gelişme olduğunu ve bunun dişsal bir faktör olduğunu savunmuştur.

Üretilen yeni teknolojiler ile üretim miktarı, kalitesi ve çeşitliliği vb. bakımından sağladığı artı değerler göz önünde bulundurulduğunda teknolojik gelişmeler ve yenilikler, uzun dönemde sürekli büyümeyi belirleyen fatörlerden biri haline gelmektedir (Taymaz ve Suiçmez 2005: 57). Teknolojik gelişmeler ile üretim sürecindeki girdilerde meydana gelecek verimlilik artışı önce maliyetlere olumlu yansıyacak daha sonra ekonomik büyümeye daha az kaynak kullanımı ve optimal verimlilik ile katk1 sağlayacaktır. Verimlilikteki bu gelişme, pozitif dışsallık yaratarak farklı sektörlerin iyileşmesinide sağlayacaktır.

\section{Büyümenin Muhasebesi}

Toplam faktör verimliliğine ilişkin ilk çalışma Solow (1956) tarafindan gerçekleşrilmiştir. Çalışmasında üretimin, emeğin ve sermayenin tam rekabet piyasa koşullarında kullanılarak, eksik istihdamın ortadan kaldırılabileceği ve ekonomideki aksaklıkların emek ve sermaye miktarlarındaki değişim ile düzeltilebileceği savunulmaktadır. Solow, Cobb - Douglas üretim fonksiyonundan hareketle aşağıdaki üretim fonksiyonu ile ifade etmiştir (Solow 1956: 84 ve Işı1k 2016).

$$
\mathrm{Y}=\mathrm{A} \cdot \mathrm{K}^{\alpha} \cdot \mathrm{L}^{1-\alpha}
$$

$\mathrm{Y}=$ Üretim Miktar1

$\mathrm{A}=$ Teknoloji

$\mathrm{L}=$ İşgücü Miktarı

$\mathrm{K}=$ Sermaye Miktar

$\alpha=$ Sermayenin Üretim Esnekliği

$(1-\alpha)=$ Emeğin Üretim Esnekliği 
Neo-Klasik büyüme modellerinde, sermaye ve emeğin üretimde yarattığı büyüme payı milli gelir büyümesinden çıkartılır. Kalan kısım ise teknolojiden kaynaklanan bir büyümedir. Bu arta kalan kısıma toplam faktör verimliliği denir. Solow ise üretimde meydana gelen değişimin girdi faktörleri ile açıklanamayan kısmını ‘Solow Artığı' olarak tanımlamıştır.

Teknolojik gelişmenin dışsal bir faktör veya sabit olarak kabul edildiği varsayımı altında üretim fonksiyonu aşağıdaki gibi gösterilir:

$$
\mathrm{Y}=\mathrm{A} \cdot \mathrm{f}(\mathrm{K}, \mathrm{L})
$$

Yukarıda yer alan üretim fonksiyonuna göre; sermaye veya emek faktörlerinde meydana gelen bir değişme, üretim miktarının değişmesini sağlamaktadır. Bu değişimin payında, teknolojik gelişme sabit olduğundan sadece sermaye ve emek faktörleri ile açıklanabilir.

Sermaye miktarında meydana gelecek olan bir değişmenin üretim miktarını ne kadar değiştireceği sermayenin marjinal verimliliği (MPK) ile tanımlanır. O halde; sermayenin marjinal verimliliği aşağıdaki gibi formülize edilebilir.

$$
\mathrm{MPK}=\frac{\Delta \mathrm{Y}}{\Delta \mathrm{K}} \quad \text { ise } \quad \Delta \mathrm{Y}=\mathrm{MPK} . \Delta \mathrm{K}
$$

Yukarıdaki denklemlere göre; üretimdeki değişmenin, sermayedeki değişime oranı MPK' y1 ifade ederken sermayede meydana gelen bir birimlik artış, MPK kadar üretim artışına sebep olmaktadir.

İşgücü miktarında meydana gelecek olan bir değişmenin üretim miktarını ne kadar değiştireceği emeğin marjinal verimliliği (MPL) ile tanımlanır. Emeğin marjinal verimliliği aşağıdaki gibi ifade edilir.

$$
\mathrm{MPL}=\frac{\Delta \mathrm{Y}}{\Delta \mathrm{L}} \quad \text { ise } \quad \Delta \mathrm{Y}=\mathrm{MPL} . \Delta \mathrm{L}
$$

Yukarıdaki eşitliklere göre; üretimdeki değişmenin, emek miktarındaki değişime oranı MPL olarak ifade edilirken, emek miktarında meydana gelen bir birimlik artış, MPL kadar üretim miktarı artışına sebep olmaktadır. 
Üretim fonksiyonu ( $\mathrm{Y}=\mathrm{A} \mathrm{f}(\mathrm{K}, \mathrm{L})$ ) göz önünde bulundurulduğunda, üretimdeki artışın sermaye ve emek miktarındaki artış ile açıklandığı aşağıdaki eşitlik ile ifade edilebilir.

$$
\Delta \mathrm{Y}=(M P K . \Delta K)+(\mathrm{MPL} . \Delta \mathrm{L})
$$

(MPK . $\Delta \mathrm{K}$ ), üretimdeki değişmenin sermaye miktarındaki değişmeden kaynaklandığı payı ifade ederken, (MPL . $\Delta \mathrm{L}$ ) ise üretimdeki değişimin emek miktarındanki değişmeden kaynaklandığı payı gösterir.

Üretimdeki büyüme veya GSYİH büyüme hızı, üretim faktörlerinin değişim oranı ile bu üretim faktörlerinin önceki dönem GSYIH içersindeki payları çarpımı toplamına eşittir (Dilber 2018: 58-59). Bu denklem aşağıdaki gibi yazılabilir.

$$
\frac{\Delta \mathrm{Y}}{\mathrm{Y}}=\left(\frac{\Delta \mathrm{K}}{\mathrm{K}}\right) \cdot\left(\frac{\mathrm{MPK} \cdot \Delta \mathrm{K}}{\mathrm{Y}}\right)+\left(\frac{\Delta \mathrm{L}}{\mathrm{L}}\right) \cdot\left(\frac{\mathrm{MPL} \cdot \Delta \mathrm{L}}{\mathrm{Y}}\right)
$$

$(\mathrm{MPK} . \Delta \mathrm{K})=$ Sermayenin değerini (faizi)

$(\mathrm{MPL} . \Delta \mathrm{L})=$ İşgücünün değerini (ücreti)

$(\mathrm{MPK} . \Delta \mathrm{K}) / \mathrm{Y})=$ Sermayenin üretimdeki payını

$(\mathrm{MPL} . \Delta \mathrm{L}) / \mathrm{Y})=$ İşgücünün üretimdeki payını

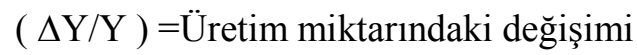

$(\Delta \mathrm{K} / \mathrm{K})=$ Sermaye miktarındaki değişimi

$(\Delta \mathrm{L} / \mathrm{L})=$ Emek miktarındaki değişimi $\quad$ ifade etmektedir (Dilber 2018: 58).

Yukarıdaki eşitliğe göre, üretimdeki artış teknolojik gelişmenin sabit kalması koşulu altında sermaye ve emek faktörlerindeki artış ile açıklanmaktadır. O halde; GSYİH büyüme hızı, sermaye ve emek faktörlerinin değişim oranı ile GSYİH içersindeki paylarına bağlıdır.

Teknolojik gelişmenin, üretim fonksiyonu üzerindeki etkisinin sabit olmadığını veya artık teknolojik gelişmenin içsel bir faktör olarak varsayıldığı bir üretim fonksiyonu aşağıdaki gibi ifade edilir;

$$
\mathrm{Y}=\mathrm{f}(\mathrm{K}, \mathrm{L}, \mathrm{A})
$$


Yukarıdaki büyüme fonksiyonuna göre; üretim miktarındaki değişim sermaye faktörü, emek faktörü ve teknolojik değişim tarafından açıklanmaktadır. Üretim miktarında meydana gelen artışın, sermaye ve emek faktörlerindeki artışın dışında kalan kısmı teknolojik gelişmeden veya diğer adıyla toplam faktör verimliliğinden kaynaklanmaktadır (Dilber 2018: 59). Toplam faktör verimliliğindeki değişim $(\Delta \mathrm{A} / \mathrm{A})$ şeklinde ifade edilirken, GSYİH büyüme hızı ise aşağıdaki denklem ile gösterilebilir;

$$
\frac{\Delta \mathrm{Y}}{\mathrm{Y}}=\left(\frac{\Delta \mathrm{K}}{\mathrm{K}}\right) \cdot\left(\frac{\mathrm{MPK} \cdot \Delta \mathrm{K}}{\mathrm{Y}}\right)+\left(\frac{\Delta \mathrm{L}}{\mathrm{L}}\right) \cdot\left(\frac{\mathrm{MPL} \cdot \Delta \mathrm{L}}{\mathrm{Y}}\right)+\frac{\Delta \mathrm{A}}{\mathrm{A}}
$$

İfade edilen denkleme göre; GSYİH büyüme hızı, emek ve sermaye faktörlerinin artış oranlarına, bu faktörlerin GSYİH içindeki paylarına ve toplam faktör verimliliğindeki artışa bağlı olarak açıklanmaktadır.

\section{Literatür}

Çalışmanın bu bölümünde konu ile ilgili yapılan bazı çalışmalar yer almaktadır. Ele alınan çalışmalar; yılı, çalışmanın yapıldığı ülke, kullanılan değişkenler, kullanılan analiz ve yöntem ve elde edilen bulgular şeklinde değerlendirilmektedir.

Sayg111, Cihan ve Yurtoğlu (2002), 1972 - 2000 dönem aralığında Türkiye ekonomisi için makro ve ana sektörler itibariyle sermaye birikimini yatırım ve milli gelir verileri ile tahmin etmektedirler. Sermaye birikimi ve verimlilik artışı arasında çift yönlü ilişki sonucuna varılmıştır. Ayrıca elde edilen sonuçlara göre; ekonomik büyüme ve sermaye birikimi arasında yakın bir ilişki tespit edilmiştir.

Taymaz ve Suiçmez (2005), çalışmalarında 1923-2003 yılları arasında Türkiye' de uzun dönemde, ekonomik gelişim süresinde verimlilik artışının katkısını ortaya koymak, 2001 krizi ve sonrası dönemde imalat sanayideki emek verimliliği ve diğer değişkenlerdeki değişimin nasıl olduğunu ve verimliliğe dayalı büyüme politikalarına ilişkin öneriler sunmayı amaçlamışlardır. İndeks hesaplama ile çeşitli analizler gerçekleştirilmiştir. Uzun dönemde ekonomik büyümenin en önemli kaynağının teknolojik gelişme olduğu sonucuna ulaşılmıştır.

Tuncer ve Tunç (2006), 1980-2004 yılları arasında Türkiye ekonomisi için tarım, madencilik, imalat sanayi, enerji ve altyapı hizmetleri olmak üzere beş ana sektör seviyesinde büyümenin kaynaklarını araştırmışlardır. Büyümenin en önemli kaynağının sermaye birikimi olduğu yönünde bulgular elde edilmiştir. 
Vergil ve Abasız (2008), 1968- 2006 dönemi yıllık verileri ile Türkiye için toplam faktör verimliliği tahmini ve toplam faktör verimliliğinin ekonomik büyüme üzerine olan etkisi Collins Bosworth Varyans Ayrıştırması ve En Küçük Kareler Yöntemi ile test etmişlerdir. Toplam faktör verimliliğinin ekonomik büyüme üzerinde pozitif etki ettiği sonucuna ulaşmışlardır.

Adak (2009), çalışmasında 1987 - 2007 yılları arasında Türkiye için toplam faktör verimliliğive ekonomik büyüme arasındaki nedensellik ilişkisini azalan kareler yöntemi ile regresyon analizi gerçekleştirmiştir. Analiz sonuçlarına göre; toplam faktör verimliliği ile ekonomik büyüme arasında doğrusal bir ilişki tespit edilmiştir.

Açıkgöz ve Çatalbaş (2010), 1968 - 2006 dönemi Türkiye için ekonomik büyüme ve toplam faktör verimliliği arasındaki ilişkiyi parametrik olmayan regresyon analizi ile araştırmışlardır. Bulgulara göre; 1980 öncesi dönemde büyümenin kaynağı sermaye birikimi iken, 1980 sonrası dönemde 1991-95 yılları dışında toplam faktör verimliliğinden kaynaklanan bir büyüme olduğu tespit edilmiştir.

Arısoy (2011), çalışmasında 1968- 2006 dönem aralığına ait yıllık verilerle Türkiye için fiziksel sermaye ve ekonomik büyüme arasındaki ilişkiyi AK Model çerçevesinde VAR analizi ile test etmiştir. Elde edilen bulgular, fiziksel sermaye uzun dönemde büyüme oranı üzerinde etkili olmadığ yönündedir.

Atiyas ve Bakis (2013), 1970 - 2011 yılları arasında Türkiye'de büyümenin kaynaklarını büyüme muhasebesi yaklaşımı ile incelemişlerdir. Elde edilen sonuçlara göre; 2000'li yı1larda gözlemlenen yüksek milli gelir artışı üretim faktörleri artışından değil, toplam faktör verimliliği artışından kaynaklandığı tespit edilmiştir. Tarım, hizmetler ve sanayi sektörleri için toplam faktör verimliliği hesaplanmış, özellikle tarım sektörü içindeki payı yıllar itibariyle pozitif yönde değişim göstermiş̧ir.

Ateş (2013), yaptığ1 çalışmada 1981-2007 dönemine ait çeyreklik verilerle Türkiye için fiziksel sermaye yatırımlarının ekonomik büyüme oranı ile ilişkisini ARDL sınır testi yaklaşımı ile test etmiştir. Elde edilen sonuçlara göre; fiziksel sermaye yatırımlarının ekonomik büyüme üzerindeki etkisi kısa dönemde, uzun döneme göre daha fazladır.

Kolsuz ve Yeldan (2014), 1980- 2010 y1lları arasında Türkiye için milli gelir ile işgücü verileri ve sermayenin faktör payı verileri ile ekonomik büyümenin kaynakları üzerine olan etkilerini incelemişlerdir. Elde ettikleri sonuçlara göre; sanayi sektörünün göreceli olarak önemini yitirdiği ve hizmetler ve inşaat sektörlerine dayalı bir büyümenin gerçekleştiği sonucuna varmışlardır. Emek faktörünün katkısı yarı yarıya azalırken, ithal sermaye faktörünün katkısı \% 50’ den \% 67’ye kadar çıktığg tespit edilmiştir.

Iş1k (2016), çalışmasında 1990-2014 yıllarını kapsayan dönemde, Türkiye için ekonomik büyüme ve toplam faktör verimliliği değişkenlerini ele almıştır. Lineer azalan kareler metodu ve ADF 
birim kök testi ile regresyon analizi gerçekleştirilmiştir. Elde edilen sonuçlara göre; Türkiye'nin 1990-2014 yılları arasında toplam faktör verimliliği ve ekonomik büyüme arasında anlamlı bir lineer ilişki tespit edilmiştir.

Gömleksiz, Şahbaz ve Mercan (2017), 1993-2014 yılları arasında 12 OECD ülkesi için beşeri sermaye, Ar-Ge, ticari dışa açıklık ve ileri teknolojili ürün ithalatının toplam faktör verimliliği üzerindeki etkisi Panel Eşbütünleşme analizi ile gerçekleştirmişlerdir. Analiz sonuçlarına göre; Ar-Ge, ticari dışa açıklık ve ileri teknolojili ürün ithalatının verimlilik artışı üzerinde anlamlı sonuç elde edilirken, beşeri sermayeye ilişkin anlamlı bir bulgu elde edilememiştir.

İsabetli ve Tunalı (2018), çalışmalarında 1995-2016 dönem aralığında Türkiye'nin de içinde bulunduğu 123 ülke için toplam faktör verimliliği ve GSYH arasındaki ilişki çok boyutlu panel veri yöntemi ile araştırmışlardır. Bulgulara göre; ekonomik kriz dönemlerinin ve gelir gruplarının toplam faktör verimliliği üzerindeki etkisi negatif yönlü iken, ülekler özelinde negatif ve pozitif ilişkiler tespit edilmiştir. Türkiye için toplam faktör verimliliği üzerinde pozitif etki gözlenmiştir.

\section{Veri Seti, Yöntem Ve Ampirik Bulgular}

Gayri Safi Yurtiçi Hasıla (Y), sermaye (K), emek miktarı (L) ve toplam faktör verimliliği (A) değişkenlerinin zaman içersindeki değişimi aşağıda sırasıyla tablo 1, tablo 2 , tablo 3 ve tablo 4' te gösterilmiştir. Sermayeyi oluşturan değişken; BİT (Bilgi İletişim ve Teknolojileri) varlıkları ve BİT olmayan varlıkların toplamından oluşmaktadır. Değişkenlere ait veriler 'The Conference Board' resmi sitesinden temin edilmiştir.

Tablo 1: Türkiye için Gayri Safi Yurtiçi Hasıla Değerleri (1980-2016)

\begin{tabular}{|ll|ll|ll|ll|}
\hline 1980 & -0.12358 & 1990 & 6.774722 & 2000 & -2.86453 & 2010 & -2.69057 \\
1981 & -6.62565 & 1991 & -0.89549 & 2001 & -1.95621 & 2011 & 0.293611 \\
1982 & 0.153962 & 1992 & 5.305683 & 2002 & -2.01374 & 2012 & -0.55602 \\
1983 & -0.26048 & 1993 & 0.330885 & 2003 & -0.12439 & 2013 & 0.741921 \\
1984 & 0.543618 & 1994 & -1.72529 & 2004 & 0.687293 & 2014 & -0.38189 \\
1985 & -0.1091 & 1995 & -2.23757 & 2005 & -0.06302 & 2015 & 0.172754 \\
1986 & 0.358957 & 1996 & -0.0246 & 2006 & -0.20384 & 2016 & -0.46949 \\
1987 & 0.236758 & 1997 & 0.071662 & 2007 & -0.28542 & & \\
1988 & -0.5438 & 1998 & -0.58038 & 2008 & -0.82851 & & \\
1989 & -0.70276 & 1999 & -2.13217 & 2009 & -6.72519 & & \\
\hline
\end{tabular}

Kaynak: The Conference Board (https://www.conference-board.org/data/productivity.cfm) Erişim Tarihi: 22.06.2018

Tablo 1'de yer alan veriler dikkate alındığında 1981 ve 2009 yıllarında sirasıyla büyüme rakamları \% -6.62564898 ve \% -6.725190501 olarak en düşük seviyelerde gerçekleşmiştir. Büyümenin pozitif değerler gösterdiği en yüksek oran ise 1990 ve 1992 yıllarında sırasıyla \% 
6.774721503 ve \% 5.305682643 olarak meydana gelmiştir. Ayrıca 1991 yılında \% -0.895490029 olarak keskin bir düşüş gerçekleştiği de görülmektedir.

Tablo 2: Türkiye İçin Sermaye Değerleri (1980-2016)

\begin{tabular}{|ll|ll|ll|ll|}
\hline 1980 & -0.64644 & 1990 & 0.398764 & 2000 & 0.560785 & 2010 & 0.487265 \\
1981 & 2.073786 & 1991 & -0.07737 & 2001 & -0.73924 & 2011 & 0.371978 \\
1982 & 0.132468 & 1992 & -0.21466 & 2002 & 1.113372 & 2012 & -0.13074 \\
1983 & -0.2054 & 1993 & 0.779985 & 2003 & 0.620296 & 2013 & 0.102034 \\
1984 & 0.253481 & 1994 & -0.54945 & 2004 & 0.631195 & 2014 & -0.04919 \\
1985 & 0.338449 & 1995 & 0.14292 & 2005 & 0.116763 & 2015 & 0.001544 \\
1986 & 0.023265 & 1996 & 0.261369 & 2006 & 0.020719 & 2016 & -0.05889 \\
1987 & -0.03601 & 1997 & 0.345879 & 2007 & -0.1029 & & \\
1988 & -0.16068 & 1998 & -0.27845 & 2008 & -0.19832 & & \\
1989 & -0.08645 & 1999 & -0.42259 & 2009 & -0.4582 & & \\
\hline
\end{tabular}

Kaynak: The Conference Board (https://www.conference-board.org/data/productivity.cfm) Erişim Tarihi: 22.06.2018

Not: Sermaye rakamları BİT varlıkları ve BİT olmayan varlıkların toplamından oluşmaktadır.

1980 ve 2016 dönemleri arasında Tablo 2’ de de görüldüğü üzere sermaye rakamları inişli çıkışlı değerlerden oluşmaktadır. Sermaye değişkeni; BíT varlıkları ve BíT olmayan varlıklardan oluşan toplam sermaye hizmetlerinin büyüme oranı olarak ifade edilmektedir.

Tablo 3: Türkiye içcin Emek Miktarı (1980-2016)

\begin{tabular}{|ll|ll|ll|lc|}
\hline 1980 & 0.377485 & 1990 & -0.60921 & 2000 & -1.43884 & 2010 & -10.4596 \\
1981 & -0.4465 & 1991 & 1.516989 & 2001 & -1.15212 & 2011 & 0.001094 \\
1982 & 0.372835 & 1992 & -0.43625 & 2002 & -2.13255 & 2012 & -0.5823 \\
1983 & -0.13228 & 1993 & -2.68786 & 2003 & 2.107332 & 2013 & -0.36207 \\
1984 & -4.27276 & 1994 & -2.54561 & 2004 & -1.76233 & 2014 & 0.02876 \\
1985 & -2.64277 & 1995 & -0.62359 & 2005 & 4.115246 & 2015 & 0.6396 \\
1986 & -0.67586 & 1996 & 0.635362 & 2006 & -0.29255 & 2016 & -0.62521 \\
1987 & -0.87771 & 1997 & -1.18744 & 2007 & -1.08452 & & \\
1988 & 7.97581 & 1998 & -5.2328 & 2008 & -9.69871 & & \\
1989 & 2.792883 & 1999 & 0.144715 & 2009 & -1.3833 & & \\
\hline
\end{tabular}

Kaynak: The Conference Board (https://www.conference-board.org/data/productivity.cfm) Erişim Tarihi: 22.06.2018

Tablo 3' te yer alan emek miktarındaki değişim ise en yüksek oran \% 7.975810225 olarak 1988 y1lında gerçekleşmiştir. 2008 ve 2010 yllında ise sırasıyla \% -9.698713383 ve \% 10.45962822 olarak gerçekleştiği görülmektedir. 
Tablo 4: Türkiye İçin Toplam Faktör Verimliliği (1980-2016)

\begin{tabular}{ll|ll|ll|ll|}
1980 & 0.012982 & 1990 & -2.25916 & 2000 & -1.5483 & 2010 & -1.31134 \\
1981 & -2.16393 & 1991 & -1.69382 & 2001 & -2.70401 & 2011 & 0.4163 \\
1982 & -0.07267 & 1992 & -1.5329 & 2002 & -1.52019 & 2012 & -1.37516 \\
1983 & -0.5267 & 1993 & 3.333926 & 2003 & -0.40798 & 2013 & -3.26149 \\
1984 & 2.413932 & 1994 & -2.45111 & 2004 & 0.944142 & 2014 & -1.04471 \\
1985 & -1.12388 & 1995 & -1.23897 & 2005 & -0.79219 & 2015 & -0.15507 \\
1986 & -5.8315 & 1996 & -0.58967 & 2006 & -1.44855 & 2016 & 16.17197 \\
1987 & 0.933707 & 1997 & 1.940745 & 2007 & 0.804708 & & \\
1988 & -0.96638 & 1998 & -1.48312 & 2008 & 5.28023 & & \\
1989 & -26.7785 & 1999 & 3.798883 & 2009 & 0.573309 & & \\
\hline
\end{tabular}

KAYNAK: The Conference Board (https://www.conference-board.org/data/productivity.cfm) Erişim Tarihi: 22.06.2018

Türkiye için yaklaşık olarak tablo 4'te de görüldüğü üzere toplam faktör verimliliği 1989 yılı haricinde durağan bir şekilde seyir göstermektedir. 1989 yılında meydana gelen azalma \% 26.77853227 olarak gerçekleşmiştir.

Çalışmanın devamında elde edilen veri seti doğrultusunda değişkenlerin durağanlık analizi için ADF (Augmented Dickey Fuller) (1979) ve PP (Phillips Perron) birim kök testleri gerçekleştirilecektir. Durağanlığı elde edilen değişkenlerin ardından uygun gecikme uzunluğu araştırılacaktır. Tespit edilen gecikme uzunluğundan sonra Johansen Eşbütünleşme Testi uygulayarak değişkenler arasındaki uzun dönemli ilişkinin varlığı sınancaktır. Eşbütünleşik olmaları durumunda Hata Düzeltme Modeli (VECM) kurularak test edilecektir.

\section{ADF ve PP Birim Kök Testleri}

Durağanlık kavramı; zaman serisi verilerinin belirli bir zaman periyodunda sürekli olarak artma veya azalmanın olmadığı, verilerin zaman süresince bir yatay eksen boyunca dağılım gösterdiği ifade eder. Başka şekilde ifade etmek gerekirse zaman serisi verilerinin sabit bir ortalama etrafında dalgalandığı ve bu dalgalanma varyansının özellikle zaman boyunca sabit kaldığı biçiminde tanımlanır (Çınar ve Sevüktekin 2014: 239). Granger ve Newbold (1974), yaptıkları çalışmalarda durağan olmayan zaman serilerinin uzun dönemde sapmalı standart hata ürettiğini ve bu yüzden değişkenlerin durağan yapıya sahip olması gerektiğini ileri sürmüştür (Granger ve Newbold 1974: 113). 
Tablo 5: ADF Birim Kök Testi Sonuçları

\begin{tabular}{|c|c|c|c|c|c|c|}
\hline \multirow{2}{*}{} & \multicolumn{3}{|c|}{ DÜZEYDE } & \multicolumn{3}{c|}{ 1. FARK } \\
\cline { 2 - 7 } & Sabitli & $\begin{array}{c}\text { Sabitli Ve } \\
\text { Trendli }\end{array}$ & $\begin{array}{c}\text { Sabitsiz Ve } \\
\text { Trendsiz }\end{array}$ & Sabitli & $\begin{array}{c}\text { Sabitli Ve } \\
\text { Trendli }\end{array}$ & $\begin{array}{c}\text { Sabitsiz Ve } \\
\text { Trendsiz }\end{array}$ \\
\hline \multirow{2}{*}{ Y } & -5.306194 & -5.275428 & -5.137111 & -11.41909 & -11.30447 & -11.55818 \\
& $(0.0001)^{*}$ & $(0.0007)^{*}$ & $(0.0000)^{*}$ & $(0.0000)^{*}$ & $(0.0000)^{*}$ & $(0.0000)^{*}$ \\
\hline \multirow{2}{*}{ K } & -7.900396 & -8.069675 & -7.324943 & -7.921511 & -7.838263 & -8.002911 \\
& $(0.0000) *$ & $(0.0000)^{*}$ & $(0.0000)^{*}$ & $(0.0000)^{*}$ & $(0.0000)^{*}$ & $(0.0000)^{*}$ \\
\hline \multirow{2}{*}{$\mathrm{L}$} & -5.277678 & -5.336527 & -2.752099 & -11.18028 & -11.01688 & -11.34844 \\
& $(0.0001)^{*}$ & $(0.0006)^{*}$ & $(0.0074)^{*}$ & $(0.0000)^{*}$ & $(0.0000)^{*}$ & $(0.0000)^{*}$ \\
\hline \multirow{2}{*}{ A } & -4.711451 & -5.077405 & -4.715594 & -8.385958 & -8.337215 & -8.486013 \\
& $(0.0005)^{*}$ & $(0.0011)^{*}$ & $(0.0000)^{*}$ & $(0.0001)^{*}$ & $(0.0001)^{*}$ & $(0.0001)^{*}$ \\
\hline
\end{tabular}

Not: (*) değerleri \%5 anlamlılık seviyesini ifade eder.

Tablo 5' de yer alan $\mathrm{Y}, \mathrm{K}, \mathrm{L}$ ve A değişkenleri düzey seviyesinde ADF birim kök testi sonuçlarına göre olasılık değerlerinin 0.05 anlamlılık seviyesinden küçük çıkmasından dolayı durağanlık göstermişlerdir.

Tablo 6: PP Birim Kök Testi Sonuçları

\begin{tabular}{|c|c|c|c|c|c|c|}
\hline & \multicolumn{3}{|c|}{ DÜZEYDE } & \multicolumn{3}{|c|}{ 1. FARK } \\
\hline & Sabitli & $\begin{array}{c}\text { Sabitli Ve } \\
\text { Trendli }\end{array}$ & $\begin{array}{c}\text { Sabitsiz Ve } \\
\text { Trendsiz }\end{array}$ & Sabitli & $\begin{array}{c}\text { Sabitli Ve } \\
\text { Trendli }\end{array}$ & $\begin{array}{c}\text { Sabitsiz Ve } \\
\text { Trendsiz }\end{array}$ \\
\hline$Y$ & $\begin{array}{l}-5.305644 \\
(0.0001)^{*}\end{array}$ & $\begin{array}{l}-5.275428 \\
(0.0007)^{*}\end{array}$ & $\begin{array}{l}-5.125983 \\
(0.0000)^{*}\end{array}$ & $\begin{array}{l}-14.91070 \\
(0.0000) *\end{array}$ & $\begin{array}{l}-14.90396 \\
(0.0000) *\end{array}$ & $\begin{array}{l}-15.01129 \\
(0.0000)^{*}\end{array}$ \\
\hline $\mathrm{K}$ & $\begin{array}{l}-7.774542 \\
(0.0000)^{*}\end{array}$ & $\begin{array}{l}-8.069675 \\
(0.0000)^{*}\end{array}$ & $\begin{array}{l}-7.221403 \\
(0.0000)^{*}\end{array}$ & $\begin{array}{l}-18.93392 \\
(0.0001)^{*}\end{array}$ & $\begin{array}{l}-19.20324 \\
(0.0000)^{*}\end{array}$ & $\begin{array}{l}-18.80408 \\
(0.0000) *\end{array}$ \\
\hline L & $\begin{array}{l}-5.269299 \\
(0.0001) *\end{array}$ & $\begin{array}{l}-5.388304 \\
(0.0005)^{*}\end{array}$ & $\begin{array}{l}-4.957548 \\
(0.0000)^{*}\end{array}$ & $\begin{array}{l}-15.47648 \\
(0.0000)^{*}\end{array}$ & $\begin{array}{l}-15.24037 \\
(0.0000)^{*}\end{array}$ & $\begin{array}{l}-15.74421 \\
(0.0000) *\end{array}$ \\
\hline$A$ & $\begin{array}{l}-4.715700 \\
(0.0005)^{*}\end{array}$ & $\begin{array}{l}-5.073396 \\
(0.0011) *\end{array}$ & $\begin{array}{l}-4.695463 \\
(0.0000)^{*}\end{array}$ & $\begin{array}{l}-9.849126 \\
(0.0000) *\end{array}$ & $\begin{array}{l}-10.39682 \\
(0.0000)^{*}\end{array}$ & $\begin{array}{l}-9.971975 \\
(0.0000) *\end{array}$ \\
\hline
\end{tabular}

Not: ${ }^{*}$ ) değerleri \%5 anlamlılık seviyesini ifade eder.

Bir başka durağanlık sınaması olan ve yaygın kullanılanlardan biri olan Phillips Perron birim kök testi sonuçları ADF birim kök testi sonuçları ile paralellik göstermektedir. Y, K, L ve A değişkenleri düzey seviyesinde 0.05 anlamlılık seviyesinde durağandırlar. 


\section{Veri Setinin Gecikme Uzunluğu}

Eşbütünleşme ilişkisi aranan değişkenlerin test edilebilmesi için uygun gecikme uzunluğunun tespit edilmesi gerekmektedir. Mevsimsellikten arındırılmak için logaritmaları alınan değişkenlerin gecikme uzunluğu tablo 7'de gösterilmektedir.

Tablo 7: Gecikme Uzunluğu

\begin{tabular}{|c|c|c|c|c|c|c|}
\hline $\begin{array}{c}\text { Gecikme } \\
\text { Uzunluğu }\end{array}$ & LogL & LR & FPE & AIC & SC & HQ \\
\hline 0 & -214.0427 & NA* & $9.740031^{*}$ & 13.62767 & $13.81089^{*}$ & $13.68840^{*}$ \\
\hline 1 & -199.5377 & 24.47727 & 10.80406 & 13.72111 & 14.63719 & 14.02476 \\
\hline 2 & -187.4056 & 17.43984 & 14.49285 & 13.96285 & 15.61180 & 14.50943 \\
\hline 3 & -174.2713 & 15.59702 & 19.87260 & 14.14196 & 16.52378 & 14.93146 \\
\hline 4 & -149.0635 & 23.63231 & 14.88035 & $13.56647^{*}$ & 16.68116 & 14.59890 \\
\hline 5 & -133.5382 & 10.67368 & 26.68798 & 13.59614 & 17.44369 & 14.87149 \\
\hline
\end{tabular}

Not: $(*)$ Test Sonucu Belirlenen Gecikme Sayıs1

LR (Sequential Modified LR Test Statistic/Sıralı Modifiye LR Test İstatistiği)

FPE (Final Prediction Error/Son Tahmin Hatası)

AIC (Akaike Information Criterion/Akaike Bilgi Kriteri)

SC (Schwarz Information Criterion/Schwarz Bilgi Kriteri)

HQ (Hannan-Quinn Information Criterion/Hannan-Quinn Bilgi Kriteri)

Yukarıda tablo 7'deki test sonuçlarına göre en çok yıldıza sahip olunan gecikme uzunluğu sıfır (0) olarak tespit edilmiştir.

\section{Johansen Eşbütünleşme (Koentegrasyon) Testi}

Değişkenlerin uzun dönemli ilişkisini test etmek amacıyla Johansen Eşbütünleşme testine başvurulmaktadır. Eşbütünleşme test sonuçları tablo 8 ve 9'da sırasıyla Kısıtsız Koentegrasyon İz Testi ve Kısıtsız Koentegrasyon Max Eigen Testi olarak yer verilmektedir. Olasılık değeri $>0.05$ 
durumunda $\mathrm{H}_{0}$ kabul, $\mathrm{H}_{1}$ reddedilir. Olasılık değeri $<0.05$ durumunda ise $\mathrm{H}_{0}$ red, $\mathrm{H}_{1}$ kabul edilir. $\mathrm{O}$ halde, her iki test için de geçerli olan hipotez aşağıdaki gibidir;

$\mathrm{H}_{0}$ : Değişkenler arasında eşbütünleşme ilişkisi yoktur.

$\mathrm{H}_{1}$ : Değişkenler arasında eşbütünleşme ilişkisi vardır.

Tablo 8: Kısıtsız Koentegrasyon iz Testi Sonuçları

\begin{tabular}{|c|c|c|c|c|}
\hline & Özdeğer & iz İstatistiği & 0.05 Kritik Değer & Olasilık Değeri \\
\hline NONE* & 0.732885 & 101.6936 & 40.17493 & 0.0000 \\
\hline En Çok 1* & 0.563185 & 54.17090 & 24.27596 & 0.0000 \\
\hline En Çok 2* & 0.459202 & 24.35408 & 12.32090 & 0.0003 \\
\hline
\end{tabular}

NOT: (*) Eşbütünleşmenin varlığını gösterir.

Tablo 8'de ki İz testi sonuçlarına göre olasılık değerleri none, en çok 1 ve en çok 2' de 0.05 anlamlılık seviyesinden küçük çıkmıştır. Dolayısıyla; $\mathrm{H}_{0}$ red, $\mathrm{H}_{1}$ kabul edilir. (*) ile ifade edilen değerlerde, İz testi 0.05 seviyesinde 3 eşbütünleşme denklemini göstermektedir. Değişkenler arasında eşbütünleşme ilişkisi tespit edilmiştir.

Tablo 9: Kısıtsız Koentegrasyon Max Eigen Test Sonuçları

\begin{tabular}{|c|c|c|c|c|}
\hline & Özdeğer & $\begin{array}{c}\text { Max-Eigen } \\
\text { istatistiği }\end{array}$ & 0.05 Kritik Değer & Olasılık Değeri \\
\hline NONE* & 0.732885 & 47.52274 & 24.15921 & 0.0000 \\
\hline En Çok 1* & 0.563185 & 29.81682 & 17.79730 & 0.0005 \\
\hline En Çok 2* & 0.459202 & 22.12956 & 11.22480 & 0.0004 \\
\hline
\end{tabular}

NOT: $\left(^{*}\right)$ Eşbütünleşmenin varlığını gösterir.

Tablo 9'da de Max Eigen test sonuçları yer almaktadır. Olasılık değerleri, 0.05 anlamlılık düzeyinden küçük çıkmıştır. $\mathrm{O}$ halde; $\mathrm{H}_{0}$ red, $\mathrm{H}_{1}$ kabul edilir. (*) Max Eigen testi, 0.05 anlamlılık seviyesinde 3 tane eşbütünleşme denklemini göstermektedir. 


\section{Hata Düzeltme Modeli (VECM)}

Değişkenler arasında eşbütünleşme ilişkisinin tespit edilmesi ile birlikte hata düzeltme modelinin (VECM) kurulması gerekmektedir. Aşağıdaki denklikte hata düzeltme modelinin denklemi ve tablo 10'da hata düzeltme modeline ait kat sayılar yer almaktadır.

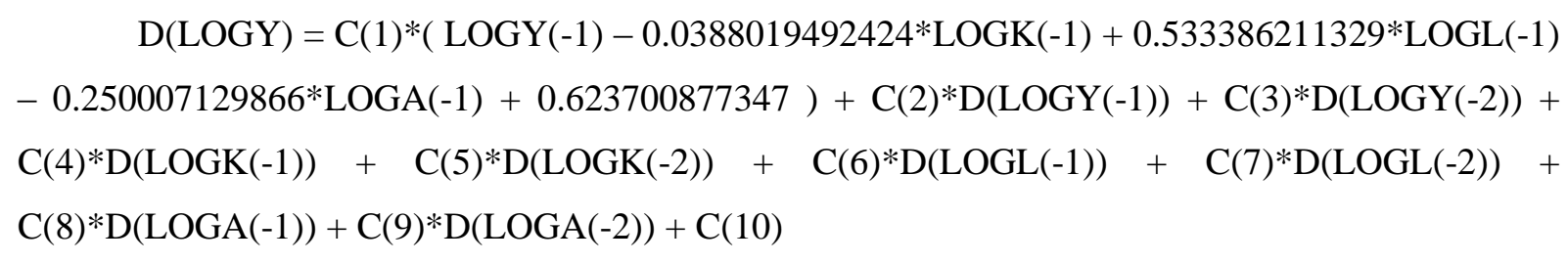

Tablo 10: Hata Düzeltme Modeli (VECM)

\begin{tabular}{|c|c|c|c|c|}
\hline & Katsayilar & Std. hata & t-istatistiği & Olasılık Değeri \\
\hline$C(1)$ & -1.219894 & 0.293900 & -4.150709 & 0.0004 \\
\hline$C(2)$ & 0.415208 & 0.264021 & 1.572630 & 0.1289 \\
\hline$C(3)$ & 0.300953 & 0.195081 & 1.542708 & 0.1360 \\
\hline$C(4)$ & 0.307701 & 0.201997 & 1.523298 & 0.1408 \\
\hline$C(5)$ & 0.711637 & 0.257077 & 2.768183 & 0.0107 \\
\hline$C(6)$ & 0.368490 & 0.132457 & 2.781954 & 0.0104 \\
\hline$C(7)$ & 0.179051 & 0.121883 & 1.469045 & 0.1548 \\
\hline$C(8)$ & -0.272660 & 0.250472 & -1.088583 & 0.2871 \\
\hline$C(9)$ & -0.338147 & 0.211736 & -1.597018 & 0.1233 \\
\hline$C(10)$ & 0.218606 & 0.228827 & 0.955332 & 0.3489 \\
\hline & $R^{2}: 0,558307$ & & F İstatistik Değeri: 0,008318 \\
\hline
\end{tabular}

C(1) uzun dönem denge ilişkisidir. Hem katsayının negatifliği hemde olasılık değerinin anlamlı çıkması uzun dönem denge eşitliğini göstermektedir. $\mathrm{R}^{2}$ ve $\mathrm{F}$ istatistik değeri de modeli anlamlı kılmaktadır. Değişkenler arasında uzun dönem nedensellik ilişkisi vardır. O halde; uzun dönemde bağımsız değişkenler (K, L ve A), bağımlı değişkeni (Y) etkilemektedir.

\section{Wald Testi}

Diğer C(x) katsayıları ise kısa dönem ilişkisiyi ifade etmektedir. K, L ve A'nın Y ile kısa dönem ilişkinin tespiti için Wald testi uygulanır. Wald testi ile elde edilen Chi- kare olasılık değerinin 0.05 'ten küçük çıkması durumunda $\mathrm{H}_{0}$ red, $\mathrm{H}_{1}$ kabul edilir. Wald testine göre; 
- K'dan Y'ye kısa dönem nedensellik ilişkisi hipotezi için;

$$
\begin{aligned}
& \mathrm{H}_{0}: \mathrm{C}(4)=\mathrm{C}(5)=0 \text { Kısa dönem nedensellik ilişkisi yoktur. } \\
& \mathrm{H}_{1}: \mathrm{C}(4)=\mathrm{C}(5) \neq 0 \text { Kısa dönem nedensellik ilişkisi vardır. }
\end{aligned}
$$

- L'den Y'ye kısa dönem nedensellik ilişkisi hipotezi için;

$$
\begin{aligned}
& \mathrm{H}_{0}: \mathrm{C}(6)=\mathrm{C}(7)=0 \mathrm{~K} \text { ısa dönem nedensellik ilişkisi yoktur. } \\
& \mathrm{H}_{1}: \mathrm{C}(6)=\mathrm{C}(7) \neq 0 \text { Kısa dönem nedensellik ilişkisi vardır. }
\end{aligned}
$$

- A'dan Y'ye kısa dönem nedensellik ilişkisi hipotezi için;

$\mathrm{H}_{0}: \mathrm{C}(8)=\mathrm{C}(9)=0$ Kısa dönem nedensellik ilişkisi yoktur.

$\mathrm{H}_{1}: \mathrm{C}(8)=\mathrm{C}(9) \neq 0$ Kısa dönem nedensellik ilişkisi vardır.

Tablo 11: Wald Testi Sonuçları

\begin{tabular}{|c|c|}
\hline K.D. Nedensellik ilişkisi & Chi-Kare Olasılık Değerleri \\
\hline K' dan GDP' ye & $0,0170<0,05$ \\
\hline L'den GDP' ye & $0,0196<0,05$ \\
\hline A' dan GDP' ye & $0,2790>0,05$ \\
\hline
\end{tabular}

Hata düzeltme modeli ve Wald testi sonucuna göre; bağımlı ve bağımsız değişkenler arasında uzun dönemli ilişkinin varlığı tespit edilmiştir. Ayrıca bağımsız değişkenler olan K ve L' den GDP'ye doğru kısa dönemli nedensellik ilişkisi tespit edilirken, A'dan GDP’ye kısa dönem nedensellik ilişkisi bulunamamıştır.

\section{Jarque - Bera Testi}

Hata terimlerinin yani artıkların normal dağılım gösterip göstermediğini Jarque-Bera testi ile sınanır. Bu teste göre; ters hipotez geçerli olduğundan olasılık değerinin 0.05 anlamlılık seviyesinden yüksek çıkması beklenir. Aşağıda tablo 12'de Jarque-Bera test sonuçları yer almaktadır. 
Tablo 12: Jarque-Bera Test Sonuçları

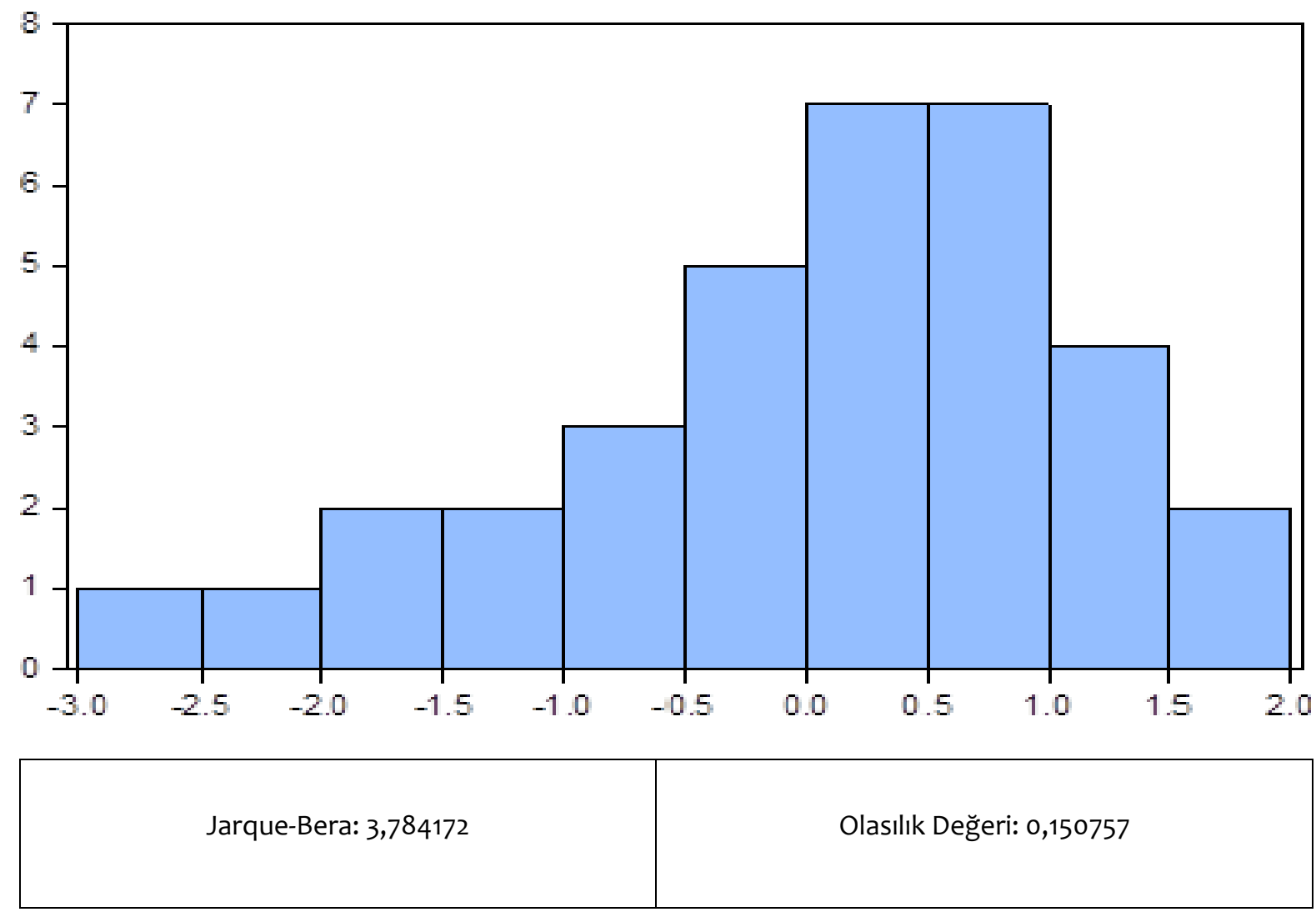

Olasılık Değerinin (0,150757), '0.05' anlamlılık seviyesinden küçük çıkması artıkların normal dağılım sergilediğini göstermektedir.

\section{Breusch-Godfrey LM Testi}

Serilerin otokorelasyon probleminin olup olmadığı Breusch-Godfrey LM testi ile her gecikme uzunluğunda test edilmiştir. Bu testte de ters hipotez mevcuttur. Olasılık değerinin 0.05 ' ten büyük olması seriler arasında otokorelasyon probleminin olmadığını göstermektedir. 
Tablo 13: Breusch-Godfrey LM Test Sonuçları

\begin{tabular}{|c|c|c|c|c|c|c|c|c|}
\hline \multicolumn{2}{|c|}{ Otokorelasyon } & \multicolumn{2}{|c|}{ Kısmi Otokorelasyon } & \multicolumn{2}{|r|}{$A C$} & PAC & $\begin{array}{c}\text { Q- } \\
\text { İstatistiği }\end{array}$ & $\begin{array}{l}\text { Olasilık } \\
\text { Değeri }\end{array}$ \\
\hline ㅁ & 1 & 망 & 1 & 1 & -0.115 & -0.115 & 0.4904 & 0.484 \\
\hline & 1 & & I & 2 & 0.129 & 0.118 & 1.1298 & 0.568 \\
\hline 1 & I & 도 & I & 3 & -0.112 & -0.088 & 1.6233 & 0.654 \\
\hline 1 & I & С & 1 & 4 & -0.056 & -0.093 & 1.7510 & 0.781 \\
\hline । & 1 & । ᄃ & I & 5 & -0.257 & -0.259 & 4.5404 & 0.474 \\
\hline 1 c & 1 & I ᄃ & I & 6 & -0.193 & -0.270 & 6.1724 & 0.404 \\
\hline 1 & 1 & I & I & 7 & 0.133 & 0.124 & 6.9697 & 0.432 \\
\hline 1 口 & 1 & 1 & I & 8 & -0.163 & -0.163 & 8.2205 & 0.412 \\
\hline & 1 & & I & 9 & 0.213 & 0.076 & 10.447 & 0.316 \\
\hline 1 & 1 & 1 & I & 10 & -0.041 & -0.073 & 10.531 & 0.395 \\
\hline 1 & 1 & 드 & 1 & 11 & 0.077 & -0.115 & 10.845 & 0.456 \\
\hline 1 & 1 & I & 1 & 12 & -0.009 & 0.033 & 10.850 & 0.542 \\
\hline $1 \square$ & 1 & $\square$ & 1 & 13 & -0.216 & -0.317 & 13.579 & 0.404 \\
\hline 1 & I & 다 & I & 14 & -0.009 & -0.099 & 13.583 & 0.481 \\
\hline 1 & I & $\mathrm{p}$ & 1 & 15 & -0.046 & 0.044 & 13.717 & 0.547 \\
\hline 1 & 1 & t & 1 & 16 & 0.102 & -0.060 & 14.430 & 0.567 \\
\hline
\end{tabular}

Test sonuçlarına göre olasılık değerleri 0.05 'tenbüyük çıktığı görülmektedir. Ayrıca tablodaki uzunluklar, çizgileri geçmemektedir. Dolayısıyla seriler arasında otokorelasyon problemi yoktur.

\section{Değișen Varyans Testi}

Değişen varyansın olup olmadığı, Breusch- Pagan - Godfrey testi ile sınanmıştır. Chi-kare olasılık değerinin 0.05 'ten büyük çıkması değişen varyansın olmadığını göstermektedir.

Tablo 14: Heteroskedas Testi: Breusch-Pagan-Godfrey

\begin{tabular}{|l|c|c|c|}
\hline \multirow{2}{*}{$R^{2}$ Gözlem: } & \multirow{2}{*}{4.654153} & Chi-Kare Olasılık(12) & 0.9685 \\
\cline { 3 - 4 } & & Chi-Kare Olasılık(12) & 0.9978 \\
\hline
\end{tabular}

Elde edilen Chi-Kare olasılık değerleri gözönünde bulundurulduğunda 0.05 'ten büyük çıktığı görülmektedir.Dolayısıyla modelde değişen varyans yoktur.

\section{Sonuç}

Bu çalışmada 1980-2016 dönem aralığında yıllık veriler kullanılarak Türkiye için üretim faktörleri olan sermaye miktarı, emek miktarı ve teknolojik gelişmeyi ifade eden toplam faktör verimliliğine ait değişkenlerin ekonomik büyümeye ile ilişkisi araştırılmıştır. 
Söz konusu çalışmada ADF ve PP birim kök testleri ile durağanlık sınaması yapılmıştır. Düzey seviyede durağanlıkları elde edilen modelin gecikme uzunluğu yapılan test sonucu sıfır (0) olarak bulunmuştur.

Değişkenlerin uzun dönemli ilişkisini test etmek amacıyla Johansen Eşbütünleşme analizi gerçekleştirilmiştir. Kısıtsız Koentegrasyon İz Testi ve Kısıtsız Koentegrasyon Max Eigen Testi sonuçlarına göre, 3 tane koentegre denklemi gözlemlenerek, eşbütünleşme ilişkisi tespit edilmiştir.

Son olarak hata düzeltme modeli kurularak yapılan analiz sonucunda, değişkenler arasında uzun dönem nedensellik ilişkisi tespit edilmiştir. O halde; uzun dönemde bağımsız değişkenler $(\mathrm{K}, \mathrm{L}$ ve A), bağımlı değişkeni (Y) etkilemektedir.

Değişkenler arası kısa dönem ilişkinin ortaya konması amacıyla uygulanan Wald testi sonucuna göre; bağımsız değişkenler olan K ve L' den GDP'ye doğru kısa dönemli nedensellik ilişkisi tespit edilirken, A'dan GDP’ye doğru kısa dönem nedensellik ilişkisi bulunamamıştır. 


\section{Kaynakça}

AÇIKGÖZ, Ş. ve ÇATALBAŞ, G. K. (2010), "Türkiye Ekonomisinde Büyümenin Kaynakları: Parametrik Olmayan Bir Yaklaşım”, Dokuz Eylül Üniversitesi İktisadi ve İdari Bilimler Fakültesi Dergisi, Cilt: 25, Sayı: 2, ss.1 - 22 .

ADAK, M. (2009), "Total Factor Productivity And Economic Growth", İstanbul Ticaret Üniversitesi Sosyal Bilimler Dergisi, Y11:8, Say1:15, ss: $49-56$.

ARISOY, İ. (2011), "Fiziksel Sermaye Yatırımları ve Büyüme İlişkisinin AK Modeliyle Sınanması: Türkiye Örneği (1968-2006)", Maliye Dergisi, 161(2), ss: 283 - 297.

ATEŞ, S. (2013), “Türkiye'de Fiziksel Sermaye Yatırımlarının Büyüme Oranına Uzun Dönemli Etkileri”, Marmara Üniversitesi İ.í.B. Dergisi, XXXIV (I), ss: 63 - 85.

ATIYAS, I. ve BAKIS, O. (2013), "Aggregate and Sectoral TFP Growth in Turkey: A Growth Accounting Exercise”, TÜSİAD - Sabancı Üniversitesi Rekabet Forumu, Working Paper No. 2013-1, ss: 1 - 26.

ÇINAR, M. ve SEVÜKTEKIN M. (2014), "Ekonometrik Zaman Serileri Analizi: Eviews Uygulamalı", Bursa: Dora Basım Yayın Dağıtım Ltd. Şti.

DATA, “THE CONFERENCE BOARD” https://www.conference-board.org/data/ Erişim Tarihi: 22.06.2018.

DICKEY, D. A. ve FULLER, W. A., (1979), "Distribution of the Estimators for Autoregressive Time Series with a Unit Root", Journal of the American Statistical Association, Cilt: 74, Say1: 366, ss: $427-431$.

DİLBER, İ. (2018), “Büyüme Teorileri”, KitapAna Yayınevi, Birinci Basım, Şubat - 2018, İZMİR.

ENGLE, R. F. ve GRANGER, C. W. J. (1987), "Co-Integration and Error Correction: Representation, Estimation, and Testing", Econometrica, Say1: 55, No: 2, ss: 251 - 276.

GÖMLEKSIZ, M., ŞAHBAZ, A. ve MERCAN, B. (2017), "Toplam Faktör Verimliliğinin Belirleyicileri Üzerine Ampirik Bir İnceleme: Seçilmiş OECD Ülkeleri Örneği”, Eskişehir Osmangazi Üniversitesi İïBF Dergisi, Ağustos 2017, Cilt: 12, Sayı: 2, ss: $65-82$.

http://ekutup.dpt.gov.tr/sermaye/110 saygilis/turkiye.pdf Erişim Tarihi: 20.06.2018.

GRANGER, C.W.J. ve NEWBOLD, P. (1974), "Spurious Regressions In Econometrics". Journal of Econometrics 2. North-Holland Publishing Company, ss: 111 - 120.

IŞIK, C. (2016), “Türkiye'de Toplam Faktör Verimliliği ve Ekonomik Büyüme İlişkisi”, Verimlilik Dergisi, Sayı: 2, ss: 45 - 56.

İSABETLİ, İ. ve TUNALI, H. (2018), "Toplam Faktör Verimliliği ve Ekonomik Büyüme İlişkisinin Çok Boyutlu Panel Veri Modelleri İle Analizi”, Akademik Araştırmalar ve Çalışmalar Dergisi, 10 (18), ss: 189 199.

KOLSUZ, G. ve YELDAN, A. E. (2014), "1980 Sonrası Türkiye Ekonomisinde Büyümenin Kaynaklarının Ayrıştııılması”, Çalışma ve Toplum, 40 (1), ss: 49 - 66.

SAYGILI, S.., CIHHAN, C. ve YURTOĞLU, H. (2002), "Türkiye Ekonomisinde Sermaye Birikimi, Büyüme ve Verimlilik: 1972-2000", Devlet Planlama Teşkilatı Ekonomik Modeller ve Stratejik Araştırmalar Genel Müdürlüğ̈̈, Yayın No: DPT. 2665, ss: 1-110.

SOLOW, R. M. (1956), "A Contribution to the Theory of Economic Growth", Quarterly Journal of Economics, c. 70, s. 1, ss: $65-94$.

SONGUR, M. (2017), “Türkiye'de Beşeri Sermaye ve Fiziksel Sermaye Arasındaki İkame Olanakları: Translog Üretim Fonksiyonu Yaklaşımı”, Çankırı Karatekin Üniversitesi İỉBF Dergisi, 7 (2), 201 - 224.

TAYMAZ, E. ve SUIÇMEZ H. (2005), “Türkiye’de Verimlilik, Büyüme ve Kriz”, Milli Prodüktivite Merkezi, ss: 1 - 69 .

The Conference Board (https://www.conference-board.org/data/productivity.cfm) Erişim Tarihi: 22.06.2018

TUNCER, İ. ve TUNÇ, T. (2006), "Türkiye Ekonomisinde Büyümenin Kaynakları: Faktör Birikimi ve Üretkenlik (1980-2004)”, KSÜ Sosyal Bilimler Dergisi, 3 (2), ss: 51 - 62.

VERGIL, H.ve ABASIZ, T. (2008), “Toplam Faktör Verimliliği, Hesaplanması ve Büyüme İlişkisi: Collins Bosworth Varyans Ayrıştırması", Kocaeli Üniversitesi Sosyal Bilimler Enstitüsü Dergisi, 16 (2), ss: 160 - 188. 